\title{
Responses of Cynodon pastures mixed with forage peanut in Southwestern Paraná, Brazil
}

\section{Respostas de pastagens do gênero Cynodon consorciadas com amendoim forrageiro no Sudoeste do Paraná}

\author{
Magnos Fernando Ziech ${ }^{1 *}$; Clair Jorge Olivo²; Ana Regina Dahlem Ziech ${ }^{1}$; \\ Gilmar Roberto Meinerz ${ }^{3}$; Alberto Luiz Gagstetter ${ }^{4}$; Jacson Rodrigo Cullmann ${ }^{4}$
}

\begin{abstract}
The genus Cynodon includes a number of grasses cultivars important for dairy farms. Although Cynodon grasses are usually established as single crops, multi-cropping them with legumes can yield important benefits such as significant reduction on fertilizer costs, increased soil fertility and the nutritional value of the forage. Therefore, the aim of this study was to evaluate the development, and the botanical and structural components of Coastcross- 1 and Tifton 85 pastures cultivated over a period of two years (planting in August 2011, last cut in April 2013) with increasing inclusion of forage peanut $(0,25,50$ and $75 \%$ planted area). The experimental design was randomized blocks, with eight treatments (pastures) and split plot (seasons), with three replicates. Measured parameters included forage mass, dry matter accumulation rate, leaf:stem ratio, dead material, and other species and forage peanut mass. The different peanut inclusion rates did not affect the pasture production parameters or the structural composition of the cultivars. With $75 \%$ of the area planted with forage peanut, the legumes represented close to $30 \%$ of the total mass. The leaf:stem ratio was highest for Tifton 85 in milder daily average temperatures, although, in this situation, both cultivars decreased the forage rate accumulation. Increasing the percentage of area planted with forage peanut also increased the participation of legumes, without interfering with the presence of dead material or other species.
\end{abstract}

Key words: Arachis pintoi. Coastcross-1. Forage mass. Forage accumulation rate. Tifton 85.

\section{Resumo}

O gênero Cynodon inclui uma série de cultivares de gramíneas importantes para a exploração leiteira. Embora essas gramíneas sejam normalmente estabelecidas singularmente, o consórcio com leguminosas pode trazer benefícios importantes, como a redução significativa nos custos de fertilizantes, aumento da fertilidade do solo e do valor nutritivo da forragem. Portanto, o objetivo do estudo foi avaliar o desenvolvimento, os componentes estruturais e botânicos de pastagens de Coastcross-1 e Tifton 85 consorciadas com amendoim forrageiro $(0,25,50$ e $75 \%$ da área implantada), submetidas a cortes, entre agosto de 2011 (plantio das pastagens) e abril de 2013 (último período de corte), totalizando dois anos de estudo. O delineamento experimental foi de blocos ao acaso, com oito tratamentos (pastagens) e parcelas subdivididas no tempo (estações), com três repetições. Avaliou-se a massa de forragem, a taxa de acúmulo de massa seca, a relação folha:colmo, o material morto, outras espécies e a massa de amendoim forrageiro. Os distintos porcentuais de área implantada com amendoim forrageiro não

\footnotetext{
${ }^{1}$ Profs. Drs., Universidade Tecnológica Federal do Paraná, UTFPR, Santa Helena, PR, Brasil. E-mail: magnos@utfpr.edu.br; ana. ziech@utfpr.edu.br

2 Prof. Dr., Universidade Federal de Santa Maria, UFSM, Santa Maria, RS, Brasil. E-mail: clairo@yahoo.com.br

3 Prof. Dr., Universidade Federal da Fronteira Sul, UFFS, Cerro Largo, RS, Brasil. E-mail: gilmarmeinerz@yahoo.com.br

${ }^{4}$ Discentes, UTFPR, Dois Vizinhos, PR, Brasil. E-mail: albertoluizg@gmail.com; jrcullmann@gmail.com

* Author for correspondence
}

Received: Oct. 16, 2014 - Approved: Sept. 20, 2016 
afetaram os parâmetros produtivos da pastagem e da composição estrutural das cultivares. A utilização de $75 \%$ da área de plantio com amendoim forrageiro promoveu participação próxima a $30 \%$ de leguminosa na massa de forragem total. A relação folha:colmo foi superior para a cultivar Tifton $85 \mathrm{em}$ temperaturas médias diárias mais amenas. Nessa condição, ambas as cultivares diminuíram a taxa de acúmulo de forragem. O percentual crescente de área implantada com amendoim forrageiro aumentou a participação da leguminosa, não interferindo quanto a presença de material morto e outras espécies.

Palavras-chave: Arachis pintoi. Coastcross-1. Massa de forragem. Taxa de acúmulo de forragem. Tifton 85.

\section{Introduction}

The genus Cynodon includes a number of cultivars that are important for dairy farms, especially due to their perenniality, rapid establishment and high forage mass production. These grasses are usually established as single crops and, because of their potential, require high levels of fertilization, especially with nitrogen, resulting in high production costs. The use of legumes in this kind of pasture can reduce spending on fertilizers and improve pastoral environment, soil fertility and the nutritional value of the forage (BARCELOS et al., 2008). Among legumes, stoloniferous forage peanut stands out for its durability, forage production capacity and potential for improving animal performance (BARBERO et al., 2010).

Legumes usually have a slow growth rate, especially as compared to Cynodon grasses, which have rapid establishment and high productivity. In fact, previous studies on multi-cropping forage peanut with Cynodon grasses have stumbled on difficulties to maintain adequate levels of participation of this legume in the pasture (PARIS et al., 2008). Thus, multi-cropping success appears to be associated with the establishment of the pastures and planting a larger area with legumes could result, once the multi-crop is established, in a $25-30 \%$ participation of the legume in forage mass, resulting in higher sustainability of the forage system. Thus, the aim of with this study was to evaluate the effects of inclusion of stoloniferous forage peanuts multicropped with Coastcross-1 or Tifton 85 grasses on the development and botanical and structural composition of the grass, over two years, in the southwestern Paraná (PR) region of Brazil.

\section{Materials and Methods}

This study was conducted in an experimental area next to the Dairy Farming Teaching and Research Unit (UNEPE) of the Universidade Tecnologica Federal do Paraná, Dois Vizinhos campus, located at $25^{\circ} 44^{\prime \prime} \mathrm{S} 53^{\circ} 04^{\prime \prime} \mathrm{W}$, at an average elevation of 520 $\mathrm{m}$. Local soil is classified as Red distroferric nitisol (BHERING; SANTOS, 2008), and local climate is considered Cfa (humid subtropical, Koppen climate classification), without a well-defined dry season, and with $22^{\circ} \mathrm{C}$ average temperature in the hottest month.

The area used for the experiments was approximately $400 \mathrm{~m}^{2}$, with two cultivars of the genus Cynodon (Tifton 85 and Coastcross-1). At the time of planting, we introduced increasing percentages $(0 \%, 25 \%, 50 \%$ and $75 \%)$ of a legume of the genus Arachis (stoloniferous forage peanut, cv. Amarillo) in the occupied area.

The planted pastures were divided in $2 \times 6$ $\mathrm{m}$ parcels. Planting was from seedlings, spaced linearly $33 \mathrm{~cm}$ apart, in rows $50 \mathrm{~cm}$ apart, in 3 replicates. Each Cynodon cultivar was planted in four arrangements: Cynodon cultivar alone; Cynodon cultivar in 3 successive rows and forage peanut in one (allowing 25\% of the area for the legume); Cynodon cultivar and forage peanut, each in 2 successive rows (50\% legume); and Cynodon cultivar in 1 row and forage peanut in 3 successive rows ( $75 \%$ legume).

Before pasture planting, weeds were controlled through manual weeding and desiccation. When the experiment started, soil analysis $(0-20 \mathrm{~cm}$ depth) was performed for the following parameters: 
$\mathrm{pH}\left(\mathrm{H}_{2} \mathrm{O}\right)=5.5 ; \mathrm{OM}(\%)=3.9 ;$ Clay $(\%)=54$; Mehlich-P $(\mathrm{mg} / \mathrm{L})=4.5 ; \mathrm{K}(\mathrm{mg} / \mathrm{L})=72 ; \mathrm{Ca}$ $(\mathrm{cmolc} / \mathrm{L})=8.8 ; \mathrm{Mg}(\mathrm{cmolc} / \mathrm{L})=3.4 ; \mathrm{H}+\mathrm{Al}$ $(\mathrm{cmolc} / \mathrm{L})=3.5$; effective CTC $(\mathrm{cmolc} / \mathrm{L})=12.6$; Al Saturation $(\%)=0.0$; Base saturation $(\%)=78.2$. Based on the chemical analysis and on CQFS RS/ SC (2004) recommendations for multi-cropping of grasses and tropical legumes, we applied 2.2 ton. ha $^{-1}$ lime (filler - PRNT $>90 \%$ ) before planting. Fertilization during pasture planting was $110 \mathrm{~kg} \cdot \mathrm{ha}^{-1}$ $\mathrm{P}_{2} \mathrm{O}_{5}$ and $60 \mathrm{~kg} \cdot \mathrm{ha}^{-1} \mathrm{~K}_{2} \mathrm{O}$, in the first year, and 60 kg.ha- ${ }^{-1}$ for both $\mathrm{P}_{2} \mathrm{O}_{5}$ and $\mathrm{K}_{2} \mathrm{O}$, in the second year. To support the establishment of Arachis in the multi-crops, we supplied $80 \mathrm{~kg} \cdot \mathrm{ha}^{-1} \cdot \mathrm{yr}^{-1}$ nitrogen (N) during planting, avoiding losses in biological $\mathrm{N}$ fixation (THOMAS, 1994). In the second year, 20 $\mathrm{kg} \cdot \mathrm{ha}^{-1} \mathrm{~N}$ was applied every two cuts (CQFS RS/ SC, 2004) totaling $60 \mathrm{~kg} \cdot \mathrm{ha}^{-1} \mathrm{~N}$ over all treatments.

This study was conducted between September 3, 2011 (planting) and April 14, 2013 (final cut), for a total of 588 days. Pastures were mowed whenever the grass reached between 20 and $25 \mathrm{~cm}$, totaling fourteen collections in the period, averaged for each season. For every collection, a $1 \mathrm{~m}^{2}$ area, representing the proportion of each multi-crop, was randomly selected for cutting at $7 \mathrm{~cm}$ above the soil. Afterwards, another cut close to the ground was performed for measurement of the residual mass within a rectangular area of $0.25 \mathrm{~m}^{2}(1.0 \times 0.25 \mathrm{~m})$. Then, the rest of the experimental area was mowed down to a $7 \mathrm{~cm}$ height with a sickle, and the residue was removed from the experimental unit with rakes.

After cutting, the samples were weighed, homogenized, subsampled and separated by species to determine botanical composition. The structural components of the grasses were also separated in leaf blade, stem and dead material + senescent. To determine the dry matter percentage (DM) of each component, the samples were weighed and dried in a forced air furnace at $60^{\circ} \mathrm{C}$ until constant weight.

The accumulation ratio was obtained by the equation (MFT - MFR)/PD, where, MFT = the total forage mass for each cutting period; MFR = mass of residual forage for the previous cut and $\mathrm{PD}=$ rest period in days.

Rainfall and average air temperature data, recorded by the INMET weather station at UNEPE, were collected during the evaluation period (Figure 1). Recorded average temperature and rainfall values were similar to annual averages.

The experimental design was randomized blocks, with eight treatments (formed pastures) and three replicates (plots) in split plot (seasons in which collections were performed). Data were subjected to analysis of variance and polynomial regression, with a $5 \%$ significance level $(\mathrm{p}=0.05)$. Analyses were performed using the statistical software Genes (CRUZ, 2006) and the means were compared by the Tukey test.

The statistical model for the analysis of the variables of the pasture was represented by Yijk $=\mu+\mathrm{Pi}+\mathrm{Bj}+$ Eij (Error A) $+\mathrm{Sk}+$ Psik + eijk (Error B), where Yijk is the dependent variables; i, treatments index (pastures); $\mathrm{j}$, repetition rate; and $\mathrm{k}$, index of split plot (seasons). $\mu$ is the mean of all observations; $\mathrm{Pi}$ is the effect of pastureland; $\mathrm{Bj}$ is the effect of the blocks; Eij is the effect of grazing within the plots (error A); Sk is the effect of the seasons; Psik is the effect of the interaction between grassland and stations, and cijk corresponds to the residual experimental error. 
Figure 1. Average monthly temperature $\left({ }^{\circ} \mathrm{C}\right)$ and rainfall $(\mathrm{mm})$. Dois Vizinhos, PR, Brazil, 2013.

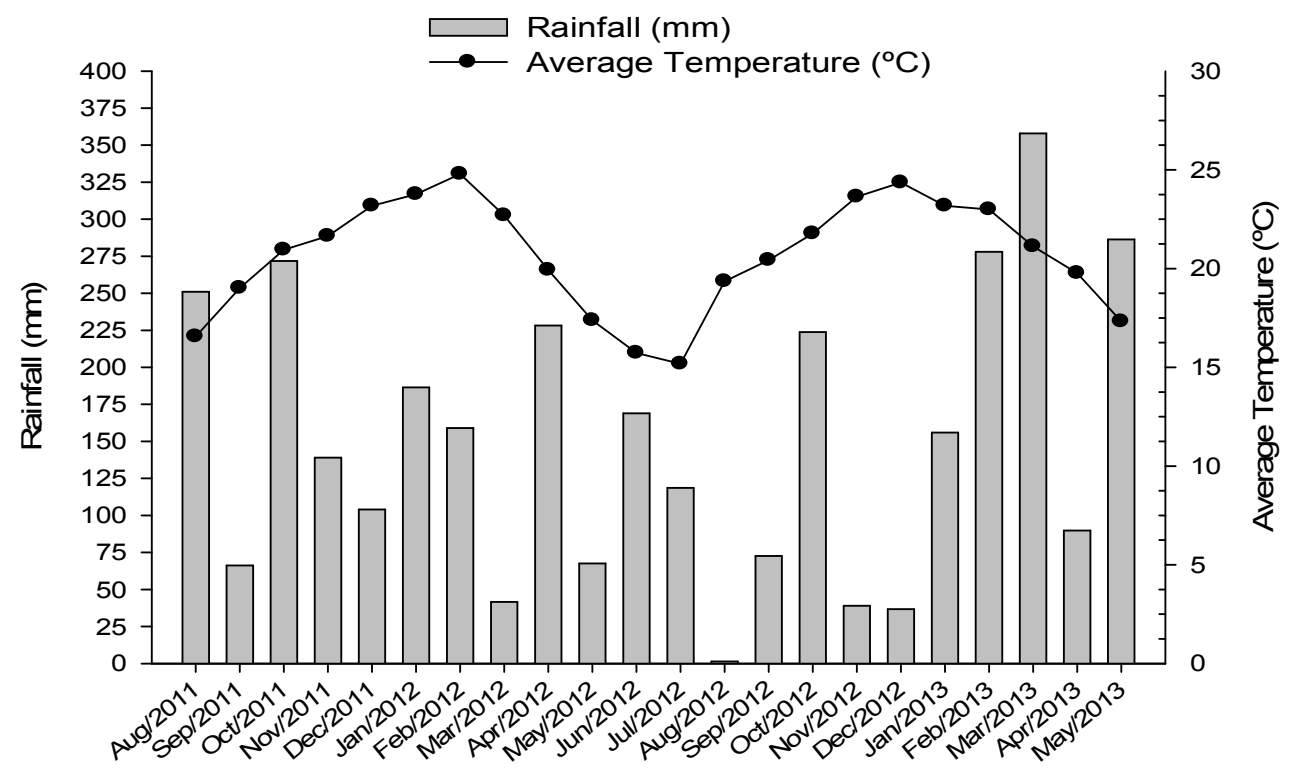

Source: Instituto Nacional de Meteorologia - Automatic weather station at Dois Vizinhos, PR, Brazil.

\section{Results and Discussion}

In the first year (beginning on December 7, 2011) eight cuts were made at day 95 after planting: 1 in spring, 3 in summer, 3 in fall and 1 in winter. In the second year (beginning on October 8, 2012) six cuts were made: 3 in spring, 2 in summer and 1 in fall, and harvest ended in late April. More cuts were performed in the first year because the winter was milder than in the second year, with fewer frosts and higher temperatures. Frosts in mid-May of the second year impacted development of the sward, preventing winter cuts.

The available forage mass was affected by the interaction between multi-crop proportion and season, as shown in Table 1. In the first evaluation period (spring 2011), both grass cultivars combined with $75 \%$ of forage peanut and Tifton 85 combined with $50 \%$ forage peanut displayed lower forage availability than the remaining conditions. This was a result of the slower establishment of the legume, together with the fewer grass seedlings in these pastures, resulting in longer time for full pasture establishment. In the second evaluation period (summer 2012), however, the available forage mass was similar among all formed pastures. During winter, Tifton 85 developed slower, failing to attain the minimum height for cutting. Thus, Coastcross-1 seems to have the highest production capacity in milder temperatures. Over the seasons, higher responses were observed for the second year due to complete soil coverage and consequent greater tillering.

The mass of residual forage was also significantly affected $(\mathrm{p}<0.05)$ by the interaction between pasture type and season (Table 1). In the spring of 2011, the pastures with $75 \%$ of the area planted with legumes had the lowest residual forage masses, regardless of grass cultivar. In winter, Tifton 85 pastures had the highest residual forage masses due to the lack of cut above $7 \mathrm{~cm}$, which meant that all the herbage mass obtained this season was concentrated in the residual forage. This persisted in the spring of 2012, possibly indicating higher tillering in this cultivar than in Coastcross-1 pastures after the cold season. In a study performed in northwestern Paraná, Brazil, using Coastcross-1 single-cropped or intercropped with forage peanut and subjected to continuous grazing, Cecato et al. (2011) found an average of 
1,333 kg.ha- ${ }^{-1} \mathrm{DM}$ in the $0-7 \mathrm{~cm}$ stratum, which is less than the 1,660 kg.ha-1 DM average found in this study for the same cultivar. Over the studied seasons, all pastures had similar residual forage mass, with the exception of Tifton $85+75 \%$ of the area planted with forage peanut in spring 2011.

Table 1. Average available and residual forage mass for two Cynodon cultivars planted as single- or multi-crop pastures with forage peanut in different seasons over two years. Dois Vizinhos, PR, Brazil, 2013.

\begin{tabular}{lccccccc}
\hline \multicolumn{7}{c}{ Average available forage mass $\left(\mathrm{kg} \mathrm{ha}^{-1} \mathrm{DM}\right)$} \\
\hline $\mathrm{CC}$ & Spr-2011 & Sum-2012 & Fall-2012 & Win-2012 & Spr-2012 & Sum-2013 & Fall-2013 \\
$\mathrm{CC}+25$ & $1744 \mathrm{Ab}$ & $1792 \mathrm{Ab}$ & $1529 \mathrm{Ab}$ & $1579 \mathrm{Ab}$ & $2650 \mathrm{Aa}$ & $2554 \mathrm{Aab}$ & $3334 \mathrm{Aa}$ \\
$\mathrm{CC}+50$ & $1656 \mathrm{Ac}$ & $1606 \mathrm{Ac}$ & $1438 \mathrm{Ac}$ & $1774 \mathrm{Abc}$ & $2792 \mathrm{Aab}$ & $3049 \mathrm{Aa}$ & $3009 \mathrm{Aa}$ \\
$\mathrm{CC}+75$ & $166 \mathrm{Ac}$ & $1570 \mathrm{Ac}$ & $1712 \mathrm{Abc}$ & $1386 \mathrm{Ac}$ & $2974 \mathrm{Aa}$ & $2640 \mathrm{Aab}$ & $3298 \mathrm{Aa}$ \\
$\mathrm{TF}$ & $1307 \mathrm{ABc}$ & $1934 \mathrm{Abc}$ & $1156 \mathrm{Ac}$ & $0 \mathrm{Bd}$ & $3127 \mathrm{Aa}$ & $2599 \mathrm{Aab}$ & $3335 \mathrm{Aa}$ \\
$\mathrm{TF}+25$ & $1087 \mathrm{ABc}$ & $2068 \mathrm{Abc}$ & $1267 \mathrm{Ac}$ & $0 \mathrm{Bd}$ & $3151 \mathrm{Aa}$ & $2855 \mathrm{Aab}$ & $3058 \mathrm{Aab}$ \\
$\mathrm{TF}+50$ & $509 \mathrm{BCDd}$ & $1898 \mathrm{Abc}$ & $1600 \mathrm{Ac}$ & $0 \mathrm{Bd}$ & $3205 \mathrm{Aa}$ & $2774 \mathrm{Aab}$ & $3335 \mathrm{Aa}$ \\
$\mathrm{TF}+75$ & $274 \mathrm{CDc}$ & $1552 \mathrm{Ab}$ & $1545 \mathrm{Ab}$ & $0 \mathrm{Bd}$ & $3544 \mathrm{Aa}$ & $2904 \mathrm{Aa}$ & $3612 \mathrm{Aa}$ \\
\hline \multicolumn{7}{c}{$\mathrm{Average} \mathrm{residual} \mathrm{forage} \mathrm{mass}\left(\mathrm{kg} h \mathrm{Ca}^{-1} \mathrm{DM}\right)$} \\
$\mathrm{CC}$ & $1491 \mathrm{Aba}$ & $1855 \mathrm{Aa}$ & $1259 \mathrm{Aa}$ & $1355 \mathrm{Ca}$ & $1791 \mathrm{Ca}$ & $1919 \mathrm{Aa}$ & $1636 \mathrm{Aa}$ \\
$\mathrm{CC}+25$ & $1757 \mathrm{Aba}$ & $1945 \mathrm{Aa}$ & $1433 \mathrm{Aa}$ & $1506 \mathrm{Ca}$ & $1941 \mathrm{BCa}$ & $1901 \mathrm{Aa}$ & $1825 \mathrm{Aa}$ \\
$\mathrm{CC}+50$ & $1478 \mathrm{Aba}$ & $1513 \mathrm{Aa}$ & $1365 \mathrm{Aa}$ & $1661 \mathrm{BCa}$ & $2044 \mathrm{BCa}$ & $1935 \mathrm{Aa}$ & $1565 \mathrm{Aa}$ \\
$\mathrm{CC}+75$ & $1250 \mathrm{Ba}$ & $1627 \mathrm{Aa}$ & $1386 \mathrm{Aa}$ & $1401 \mathrm{Ca}$ & $1925 \mathrm{BCa}$ & $2315 \mathrm{Aa}$ & $1393 \mathrm{Aa}$ \\
$\mathrm{TF}$ & $1649 \mathrm{Aba}$ & $1846 \mathrm{Aa}$ & $1684 \mathrm{Aa}$ & $2189 \mathrm{Aba}$ & $2781 \mathrm{Aa}$ & $2212 \mathrm{Aa}$ & $1753 \mathrm{Aa}$ \\
$\mathrm{TF}+25$ & $1602 \mathrm{Aba}$ & $1834 \mathrm{Aa}$ & $1787 \mathrm{Aa}$ & $2418 \mathrm{Aa}$ & $2157 \mathrm{Aba}$ & $2428 \mathrm{Aa}$ & $1787 \mathrm{Aa}$ \\
$\mathrm{TF}+50$ & $1936 \mathrm{Aa}$ & $1887 \mathrm{Aa}$ & $1799 \mathrm{Aa}$ & $2334 \mathrm{Aa}$ & $2700 \mathrm{Aa}$ & $2192 \mathrm{Aa}$ & $1608 \mathrm{Aa}$ \\
$\mathrm{TF}+75$ & $1138 \mathrm{Bb}$ & $1651 \mathrm{Aab}$ & $1708 \mathrm{Aab}$ & $2190 \mathrm{ABa}$ & $2477 \mathrm{ABa}$ & $2229 \mathrm{Aa}$ & $1481 \mathrm{Aab}$ \\
\hline
\end{tabular}

Distinct uppercase letters in the columns and lowercase letters in the rows indicate significant difference by the Tukey test ( $p$ $\leq 0.05), \mathrm{CC}=$ Coastcross -1 and $\mathrm{TF}=$ Tifton 85 ; $\mathrm{Spr}=$ Spring; Sum= Summer; Fall and Win=Winter.

Table 2 displays the analysis of the forage accumulation rate, indicating an interaction $(\mathrm{p}<0.05)$ between type of pasture and season. Coastcross-1 intercropped with forage peanut pasture $(50 \%$ planted area) had the lowest forage accumulation rate in the second year of the experiment (summer-fall 2013), although the difference was only statistically significant when compared to Tifton $85+25 \%$ planted legume pasture. Comparing seasons, both cultivars showed higher DM accumulation rates in the spring-summer and summer-fall periods of the second year. Regarding Tifton 85, production was lower in winter, for both single-crops and multi- crops. A similar trend, although not as striking, was observed for Coastcross-1. However, for pastures with this cultivar, the forage accumulation rate in winter was slightly different from the values recorded in the first post-implantation season and in the fall-winter period, indicating a more balanced forage production. This is relevant because it indicates significant production in a period when there is usually less pasture production, which is an important feature of this forage. Fagundes et al. (1999) also found higher forage accumulation rate for Coastcross-1 than for Tifton 85 during winter in São Paulo, Brazil. 
Table 2. Average forage accumulation rate for two Cynodon cultivars planted as single- or multi-crop pastures with forage peanut in different seasons over two years. Dois Vizinhos, PR, Brazil, 2013.

\begin{tabular}{lccccccc}
\hline \multicolumn{7}{c}{ Forage accumulation rate $\left(\mathrm{kg}^{-h^{-1}}\right.$.day $\left.^{-1} \mathrm{DM}\right)$} \\
& Spr 2011- & Sum-Fall & Fall-Win & Win- Spr & Spr 2012- & Sum-Fall & Spr 2011- \\
& Sum 2012 & 2012 & 2012 & 2012 & Sum 2013 & 2013 & Sum 2012 \\
\hline $\mathrm{CC}$ & $34 \mathrm{Ad}$ & $74 \mathrm{Abc}$ & $44 \mathrm{Acd}$ & $27 \mathrm{Ad}$ & $87 \mathrm{Aab}$ & $114 \mathrm{ABa}$ & $73 \mathrm{Abc}$ \\
$\mathrm{CC}+25$ & $36 \mathrm{Acd}$ & $71 \mathrm{Ab}$ & $38 \mathrm{Acd}$ & $27 \mathrm{Ad}$ & $85 \mathrm{Ab}$ & $122 \mathrm{ABa}$ & $65 \mathrm{Abc}$ \\
$\mathrm{CC}+50$ & $26 \mathrm{Ad}$ & $61 \mathrm{Abc}$ & $53 \mathrm{Acd}$ & $26 \mathrm{Ad}$ & $87 \mathrm{Aab}$ & $101 \mathrm{Ba}$ & $63 \mathrm{Abc}$ \\
$\mathrm{CC}+75$ & $15 \mathrm{Ad}$ & $64 \mathrm{Abc}$ & $51 \mathrm{Ac}$ & $18 \mathrm{Ad}$ & $88 \mathrm{Aab}$ & $116 \mathrm{ABa}$ & $62 \mathrm{Abc}$ \\
$\mathrm{TF}$ & $31 \mathrm{Ad}$ & $85 \mathrm{Aab}$ & $34 \mathrm{Acd}$ & $8 \mathrm{Ad}$ & $99 \mathrm{Aa}$ & $106 \mathrm{ABa}$ & $62 \mathrm{Abc}$ \\
$\mathrm{TF}+25$ & $28 \mathrm{Ade}$ & $87 \mathrm{Ab}$ & $41 \mathrm{Acd}$ & $7 \mathrm{Ae}$ & $86 \mathrm{Ab}$ & $128 \mathrm{Aa}$ & $62 \mathrm{Abc}$ \\
$\mathrm{TF}+50$ & $26 \mathrm{Ade}$ & $77 \mathrm{Abc}$ & $51 \mathrm{Acd}$ & $5 \mathrm{Ae}$ & $95 \mathrm{Aab}$ & $110 \mathrm{ABa}$ & $60 \mathrm{Ac}$ \\
$\mathrm{TF}+75$ & $15 \mathrm{Ac}$ & $72 \mathrm{Ab}$ & $50 \mathrm{Ab}$ & $7 \mathrm{Ac}$ & $106 \mathrm{Aa}$ & $113 \mathrm{ABa}$ & $67 \mathrm{Ab}$ \\
\hline
\end{tabular}

Distinct uppercase letters in the columns and lowercase letters in the rows indicate significant difference by the Tukey test ( $\mathrm{p}$ $\leq 0.05), \mathrm{CC}=$ Coastcross-1 and TF= Tifton 85; Spr= Spring; Sum= Summer; Fall and Win=Winter.

The leaf:stem ratio in the available forage mass also indicated interaction $(\mathrm{p}<0.05)$ between pasture type and season (Table 3). In spring 2012, and in both falls, Tifton 85 pastures had higher ratios than Coastcross -1 . Furthermore, along the seasons, the largest values were found for single-cropping and multi-cropping with $75 \%$ planted peanut in the first season studied. In Tifton 85 pastures, the highest percentage of leaves was in the fall and summer cuttings. Of note, because this cultivar did not exceed $7 \mathrm{~cm}$ in winter, it was not sampled in that season. Gonçalves et al. (2002) studied cultivars Coastcross-1, Tifton 44 and Tifton 85 subjected to different intervals between cuts throughout the four seasons of the year in Maringa, PR, Brazil, and found that the highest average leaf:stem ratios were found for Tifton 85 in fall, consistent with the results of this study.
Interaction between pasture type and seasons was also found $(p<0.05)$ for the leaf:stem ratio in the residual forage mass. The highest ratio was found for Tifton 85 in winter, which is related to the total forage mass being present in this stratum during this season. In addition, Tifton 85 showed higher values than Coastcross- 1 for all pasture types in the fall of 2012, and for multi-crops with 25 and $50 \%$ planted legumes in the fall of 2013 showing that, in milder temperatures, there is more mass accumulation in the leaf blades than in the stems of the Tifton 85 grass. In contrast, the leaf:stem ratio of pastures established with the cultivar Coastcross-1 remained stable along the seasons. Cecato et al. (2011) reported a similar ratio (0.41) in the same stratum using Coastcross-1 intercropped with forage peanut and fertilized with $100 \mathrm{~kg} \cdot \mathrm{ha}^{-1} \mathrm{yr}^{-1}$ N. In the pastures based on Tifton 85, the highest results were found in winter, once again due to the total forage mass being in this stratum. 
Table 3. Average leaf:stem ratios in the available and residual forage mass for two Cynodon cultivars planted as single- or multi-crop pastures with forage peanut in different seasons over two years. Dois Vizinhos, PR, Brazil, 2013.

\begin{tabular}{lccccccc}
\hline \multicolumn{7}{c}{ Leaf:stem ratios in the available forage mass } \\
\hline & Spr-2011 & Sum-2012 & Fall-2012 & Win-2012 & Spr-2012 & Sum-2013 & Fall-2013 \\
\hline $\mathrm{CC}$ & $1.87 \mathrm{ABa}$ & $2.13 \mathrm{Aa}$ & $1.60 \mathrm{BCab}$ & $1.33 \mathrm{Aab}$ & $1.33 \mathrm{ABab}$ & $1.30 \mathrm{Aab}$ & $0.73 \mathrm{Cb}$ \\
$\mathrm{CC}+25$ & $1.67 \mathrm{Ba}$ & $2.03 \mathrm{Aa}$ & $1.53 \mathrm{Ca}$ & $1.20 \mathrm{Aa}$ & $1.27 \mathrm{Ba}$ & $1.23 \mathrm{Aa}$ & $1.10 \mathrm{BCa}$ \\
$\mathrm{CC}+50$ & $1.67 \mathrm{Bab}$ & $1.97 \mathrm{ABa}$ & $1.50 \mathrm{Cab}$ & $1.53 \mathrm{Aab}$ & $1.30 \mathrm{ABab}$ & $1.17 \mathrm{Aab}$ & $0.87 \mathrm{BCb}$ \\
$\mathrm{CC}+75$ & $2.30 \mathrm{Aa}$ & $1.70 \mathrm{ABab}$ & $1.57 \mathrm{Cab}$ & $1.37 \mathrm{Aabc}$ & $1.23 \mathrm{Bbc}$ & $1.27 \mathrm{Abc}$ & $0.60 \mathrm{Cc}$ \\
$\mathrm{TF}$ & $1.47 \mathrm{Ba}$ & $1.93 \mathrm{ABa}$ & $2.13 \mathrm{Aa}$ & $0.0 \mathrm{Bb}$ & $1.70 \mathrm{ABa}$ & $1.63 \mathrm{Aa}$ & $1.73 \mathrm{Aa}$ \\
$\mathrm{TF}+25$ & $1.43 \mathrm{Bb}$ & $1.80 \mathrm{ABab}$ & $2.43 \mathrm{Aa}$ & $0.0 \mathrm{Bc}$ & $1.80 \mathrm{Aab}$ & $1.53 \mathrm{Aab}$ & $1.73 \mathrm{Aab}$ \\
$\mathrm{TF}+50$ & $1.73 \mathrm{Ba}$ & $1.87 \mathrm{ABa}$ & $2.17 \mathrm{Aa}$ & $0.0 \mathrm{Bb}$ & $1.80 \mathrm{Aa}$ & $1.53 \mathrm{Aa}$ & $1.70 \mathrm{Aa}$ \\
$\mathrm{TF}+75$ & $1.70 \mathrm{Ba}$ & $1.50 \mathrm{Bab}$ & $2.10 \mathrm{ABa}$ & $0.0 \mathrm{Bb}$ & $1.73 \mathrm{ABa}$ & $1.43 \mathrm{Aa}$ & $1.37 \mathrm{ABa}$ \\
\hline \multicolumn{7}{c}{$\mathrm{Leaf}: \mathrm{stem} \mathrm{ratios} \mathrm{in}$ the residual forage mass } \\
$\mathrm{CC}$ & $0.49 \mathrm{Aa}$ & $0.31 \mathrm{Aa}$ & $0.48 \mathrm{Ba}$ & $0.48 \mathrm{Ba}$ & $0.38 \mathrm{Aa}$ & $0.45 \mathrm{Aa}$ & $0.40 \mathrm{Ba}$ \\
$\mathrm{CC}+25$ & $0.28 \mathrm{Aa}$ & $0.30 \mathrm{Aa}$ & $0.50 \mathrm{Ba}$ & $0.48 \mathrm{Ba}$ & $0.37 \mathrm{Aa}$ & $0.37 \mathrm{Aa}$ & $0.44 \mathrm{Ba}$ \\
$\mathrm{CC}+50$ & $0.36 \mathrm{Aa}$ & $0.32 \mathrm{Aa}$ & $0.51 \mathrm{Ba}$ & $0.50 \mathrm{Ba}$ & $0.37 \mathrm{Aa}$ & $0.50 \mathrm{Aa}$ & $0.53 \mathrm{Ba}$ \\
$\mathrm{CC}+75$ & $0.41 \mathrm{Aa}$ & $0.41 \mathrm{Aa}$ & $0.38 \mathrm{Ba}$ & $0.50 \mathrm{Ba}$ & $0.31 \mathrm{Aa}$ & $0.38 \mathrm{Aa}$ & $0.44 \mathrm{Ba}$ \\
$\mathrm{TF}$ & $0.50 \mathrm{Ab}$ & $0.40 \mathrm{Ab}$ & $0.62 \mathrm{ABab}$ & $1.06 \mathrm{Aa}$ & $0.36 \mathrm{Ab}$ & $0.50 \mathrm{Ab}$ & $0.52 \mathrm{Bb}$ \\
$\mathrm{TF}+25$ & $0.31 \mathrm{Ac}$ & $0.34 \mathrm{Ac}$ & $0.83 \mathrm{Aab}$ & $1.17 \mathrm{Aa}$ & $0.31 \mathrm{Ac}$ & $0.37 \mathrm{Ac}$ & $0.58 \mathrm{ABbc}$ \\
$\mathrm{TF}+50$ & $0.44 \mathrm{Abc}$ & $0.46 \mathrm{Abc}$ & $0.60 \mathrm{ABbc}$ & $1.10 \mathrm{Aa}$ & $0.29 \mathrm{Ac}$ & $0.43 \mathrm{Abc}$ & $0.86 \mathrm{Aab}$ \\
$\mathrm{TF}+75$ & $0.34 \mathrm{Ab}$ & $0.37 \mathrm{Ab}$ & $0.55 \mathrm{AbB}$ & $1.04 \mathrm{Aa}$ & $0.39 \mathrm{Ab}$ & $0.52 \mathrm{Ab}$ & $0.52 \mathrm{Bb}$ \\
\hline
\end{tabular}

Distinct uppercase letters in the columns and lowercase letters in the rows indicate significant difference by the Tukey test ( $\mathrm{p}$ $\leq 0.05), \mathrm{CC}=$ Coastcross -1 and $\mathrm{TF}=$ Tifton 85 ; $\mathrm{Spr}=$ Spring; Sum= Summer; Fall and Win=Winter.

Regarding forage mass (available and residual) of species with spontaneous growth, no interaction or effect of pasture type was observed (Table 4). Spontaneous growing species had a low share in the composition of the pasture in the first growing season, 3.3 and $3.7 \%$ of available and residual forage masses, respectively. Along the seasons, higher values were observed in cuts made between summer and fall of 2012, which is related mostly to the presence of Alexander grass (Urochloa plantaginea). In the second growing season, especially after the spring, there was no forage mass attributed to spontaneous growth species indicating that, regardless of the percentage of forage peanut inclusion in planting, Cynodon predominated in the pastures. The mean value obtained for spontaneous growing species, considering the two strata, was similar to that observed by Scaravelli et al. (2007) using Coastcross-1 grass in Santa Maria, state of Rio Grande do Sul, Brazil: they reported less than $10 \%$ of other species composition in the sward in the second year of implementation.

Neither pasture type nor its interaction with season affected the mass of dead + senescent available and residual material (Table 4). Regarding the seasons, the highest values were observed in the second year, when the pasture was fully established. The highest result recorded in the spring of 2012 was related to the end of the cold season, a period in which the senescence of tropical species increases. In a study using a grazing system under rotational stocking, Scaravelli et al. (2007) found similar values, ranging from 0.3 to 0.5 ton $\mathrm{ha}^{-1} \mathrm{DM}$ of dead material in Coastcross-1 pastures. 
Table 4. Spontaneous growth species (SGS) and dead material (MD) in the available (A) and residual (R) forage masses of Coastcross-1 and Tifton 85 single- and multi-crop pastures with forage peanut. Dois Vizinhos, PR, Brazil, 2013.

\begin{tabular}{lcccc}
\hline Pasture conditions & ASGS & RSGS & AMD & RMD \\
\hline Coastcross-1 & $90 \mathrm{~ns}$ & $84 \mathrm{~ns}$ & $68 \mathrm{~ns}$ & $406 \mathrm{~ns}$ \\
Coastcross-1 + 25\% AF & 80 & 77 & 61 & 415 \\
Coastcross-1 + 50\% AF & 67 & 66 & 49 & 349 \\
Coastcross-1 + 75\% AF & 59 & 53 & 62 & 275 \\
Tifton 85 & 63 & 58 & 58 & 510 \\
Tifton $85+25 \%$ AF & 91 & 88 & 53 & 435 \\
Tifton $85+50 \%$ AF & 59 & 51 & 57 & 430 \\
Tifton $85+75 \%$ AF & 64 & 54 & 62 & 354 \\
\hline CV $\%$ & 39.2 & 31.4 & 47.8 & 29.7 \\
\hline Seasons & & & & \\
\hline Spring-2011 & $63 \mathrm{bc}$ & $66 \mathrm{bc}$ & $0 \mathrm{~b}$ & $106 \mathrm{~d}$ \\
Summer-2012 & $275 \mathrm{a}$ & $215 \mathrm{a}$ & $13 \mathrm{~b}$ & $285 \mathrm{~cd}$ \\
Fall-2012 & $140 \mathrm{~b}$ & $135 \mathrm{ab}$ & $58 \mathrm{~b}$ & $364 \mathrm{bcd}$ \\
Winter-2012 & $13 \mathrm{c}$ & $48 \mathrm{bc}$ & $13 \mathrm{~b}$ & $288 \mathrm{~cd}$ \\
Spring-2012 & $11 \mathrm{c}$ & $0 \mathrm{c}$ & $78 \mathrm{ab}$ & $697 \mathrm{a}$ \\
Summer-2013 & $0 \mathrm{c}$ & $0 \mathrm{c}$ & $86 \mathrm{ab}$ & $592 \mathrm{ab}$ \\
Fall-2013 & $0 \mathrm{c}$ & $0 \mathrm{c}$ & $164 \mathrm{a}$ & $445 \mathrm{abc}$ \\
\hline CV $(\%)$ & 57.3 & 53.6 & 49.3 & 30.8 \\
\hline
\end{tabular}

Distinct lowercase letters in the columns indicate significant difference by the Tukey test $(\mathrm{p} \leq 0.05)$. Ns $=$ not significant; * significant quantitative factor, $\mathrm{p} \leq 0.05$.

Concerning the effects of increasing proportions of planted peanut, residual mass displayed a positive linear trend for all sample cuts regardless of the grass cultivar used (Figure 2), except for the mass available in the first season in which the evaluations were made, when there was no effect due to the slower development of the legume (VALENTIM et al., 2003). The largest proportions of forage peanut in the available forage mass (1034 $\mathrm{kg} \cdot \mathrm{ha}^{-1} \mathrm{DM}$, or $31.1 \%$ ) and in the residual forage mass (522 $\mathrm{kg} \mathrm{ha}^{-1} \mathrm{DM}$, or $32 \%$ ) were found with the highest proportion of planted legume $(75 \%)$ for the cuts made in the fall of 2013. These values are close to the $30 \%$ recommended by Thomas (1992), which balances the $\mathrm{N}$ losses of the system and helps maintain soil fertility and long-term productivity. In other seasons, starting in spring 2012, the values were within the range indicated by Cadish et al. (1994), who recommend a proportion of $13-23 \%$ of legume in order to keep the system sustainable.
For the multi-crop with $50 \%$ of the area planted with legumes, forage peanut participation in the forage mass was always below $13 \%$, regardless of the season. Consistently, Paris et al. (2008), evaluated multi-cropped Coastcross-1 and forage peanut in Paranavaí, PR, Brazil, and found low participation of legumes in the forage mass, ranging from 2 to $8 \%$. The higher values were observed in the multi-crop pasture without nitrogen fertilization, especially in the lower and intermediate strata. In a similar study in the same location, Ribeiro et al. (2012) observed that the participation of forage peanut in pasture forage mass ranged from 6 to $9 \%$. 
Figure 2. Regression equations for quantity of forage peanut in the available and residual masses in pastures of two Cynodon cultivars planted as single - or multi-crop pastures with forage peanut. Dois Vizinhos, PR, Brazil, 2013.

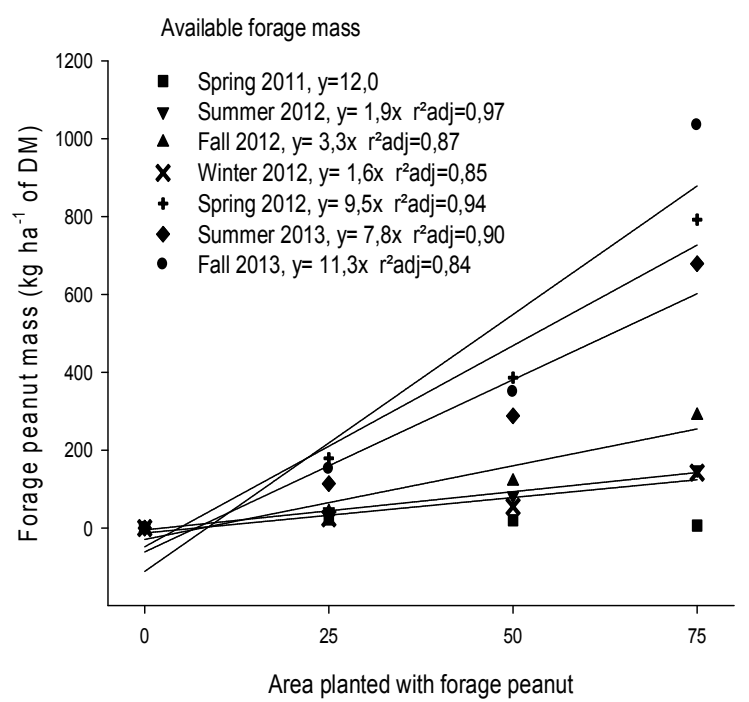

\section{Conclusions}

The different percentages of forage peanut in the planted pasture area do not affect the production parameters of the pasture and structural composition of the inter-cropped Coastcross-1 or Tifton 85 grasses.

The $75 \%$ forage peanut planting level is the most recommended, as it yields, in the second year after pasture establishment, close to $30 \%$ of legume in the pasture herbage mass.

Both cultivars decrease herbage accumulation rates during the cold season, but this effect is more pronounced for the cultivar Tifton 85 .

\section{References}

BARBERO, L. M.; CECATO, U.; LUGÃO, S. M. B.; GOMES, J. A. N.; LIMÃO, V. A.; ABRAHÃO, J. J. S.; ROMA, C. F. C. Produção animal e valor nutritivo da forragem de pastagem de coastcross consorciada com amendoim forrageiro. Arquivo Brasileiro de Medicina Veterinária e Zootecnia, Belo Horizonte, v. 62, n. 3, p .645-653, 2010.

BARCELOS, A. O.; RAMOS, A. K. B.; VILELA, L.; MARTHA JUNIOR, G. B. Sustentabilidade da produção animal baseada em pastagens consorciadas e no emprego

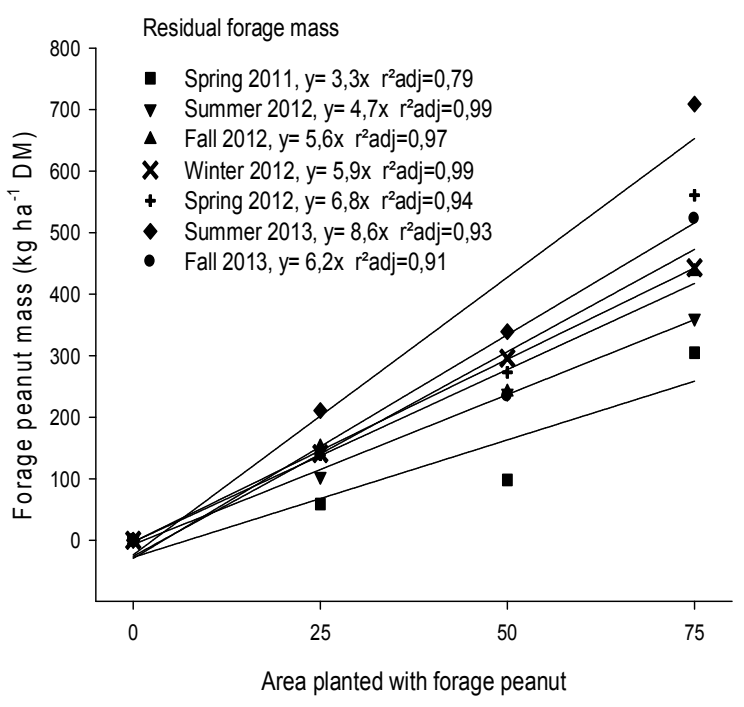

de leguminosas exclusivas, na forma de banco de proteína, nos trópicos brasileiros. Revista Brasileira de Zootecnia, Viçosa, v. 37, p. 51-67, 2008. Suplemento Especial.

BHERING, S. B.; SANTOS, H. G. Mapa de solos do estado do Paraná: legenda atualizada. Rio de Janeiro: Embrapa Floresta: Embrapa Solos, 2008.

CADISH, G.; SCHUNKE, R. M.; GILLER, K. E. Nitrogen cycling in a pure grass pasture and a grasslegume misture on a red latosol in Brazil. Tropical Grasslands, Brisbane, v. 28, n. 1, p. 43-52, 1994.

CECATO, U.; PARIS, W.; ROMA, C.; LIMÃO, V.; OLIVEIRA, E.; GOMES, J. A. N. Produção e qualidade da consorciação de coastcross com amendoim forrageiro adubada com nitrogênio em diferentes estratos sob pastejo. Revista Brasileira de Saúde e Produção Animal, Salvador, v. 12, n. 4, p. 867-880, 2011.

COMISSÃO DE QUÍMICA E FERTILIDADE DO $\mathrm{SOLO}$ - RS/SC. Manual de adubação e calagem para os Estados do Rio Grande do Sul e de Santa Catarina. 10. ed. Porto Alegre: SBCS-CQFS, 2004. 400 p.

CRUZ, C. D. Programa GENES: biometria. Viçosa: UFV, 2006. 382p.

FAGUNDES, J. L.; SILVA, S. C.; PEDREIRA, C. G. S.; SBRISSIA, A. F.; CARNEVALLI, R. A.; CARVALHO, C. A. B.; PINTO, L. F. M. Índice de área foliar, interceptação luminosa e acúmulo de forragem em pastagens de Cynodon spp. sob diferentes intensidades de pastejo. Scientia Agricola, Piracicaba, v. 56, n. 4, p. 1141-1150, 1999. 
GONÇALVES, G. D.; SANTOS, G. T.; CECATO, U.; JOBIM, C. C.; DAMASCENO, J. C.; BRANCO, A. F.; FARIA, K. P. Produção e valor nutritivo de gramíneas do gênero Cynodon em diferentes idades ao corte durante o ano. Acta Scientiarum, Maringá, v. 24, n. 4, p. 11631174, 2002.

PARIS, W.; CECATO, W.; SANTOS, G. T.; BARBEIRO, L.; AVANZZO, L.; LIMÃO, V. Produção e qualidade de massa de forragem nos estratos da cultivar coastcross-1 consorciada com Arachis pintoi com e sem adubação nitrogenada. Acta Scientiarum Animal Sciences, Maringá, v. 30, n. 2, p. 135-143, 2008.

RIBEIRO, O. L.; CECATO, U.; RODRIGUES, A. M.; SANTOS, G.T.; LUGÃO, S. M. B.; BELONI, T. Composição botânica e química da Coastcross consorciada ou não com Arachis pintoi, com e sem nitrogênio. Revista Brasileira de Saúde e Produção Animal. Salvador, v. 13, n. 1, p. 47-61, 2012.
SCARAVELLI, L. F. B.; PEREIRA, L. E. T.; OLIVO, C. J.; AGNOLIN, C. A. Produção e qualidade de pastagens de Coastcross-1 e milheto utilizadas com vacas leiteiras. Ciência Rural, Santa Maria, v. 37, n. 3, p. 841-846, 2007.

THOMAS, R. J. The role of the legume in the nitrogen cycle of productive and sustainable pastures. Grass and Forage Science, Oxford, v. 47, n. 1, p. 133-142, 1992.

Rhizobium requirements, nitrogen fixation, and nutrient cycling in forage Arachis. In: KERRIDGE, P. C.; HARDY, B. Biology and agronomy of forage arachis. Cali: CIAT, 1994. p. 109-121.

VALENTIM, J. F.; ANDRADE, C. M. S.; MENDONÇA, H. A.; SALES, M. F. L. Velocidade de estabelecimento de acessos de amendoim forrageiro na Amazônia Ocidental. Revista brasileira de Zootecnia, Viçosa, v. 32, n. 6, p. 1569-1577, 2003. 